Volume 2 Nomor 1 Tahun 2020

e-ISSN: 2685-161X

\title{
HUBUNGAN POLA ASUH ORANGTUA DENGAN KECERDASAN INTERPERSONAL
} ANAK

\author{
Resty Agustina ${ }^{1}$, Leny Marlina ${ }^{2}$, Fahmi ${ }^{3}$ \\ UIN Raden Fatah Palembang \\ e-mail: agustinaresty2@gmail.com
}

\begin{tabular}{lcrl}
\hline Diterima: & \multicolumn{1}{c}{ I Direvisi: } & I Disetujui: 2019 \\
Pendidikan Guru Raudhatul Atfhal Fakultas Agama Islam Universitas Islam Malang
\end{tabular}

\begin{abstract}
This research is motivated by various types of parenting parents that they apply to children so that it can affect the development of children's potential and intelligence, one of them is interpersonal intelligence. The problem in this research is how parents' parenting, how the child's interpersonal intelligence and is there a relationship between parenting parents with children's interpersonal intelligence. The study was conducted at RA Perwanida 4 Palembang. By using correlational methods and product moment correlation analysis techniques. Based on the analysis of the data it can be seen that the majority of parenting in RA Perwanida 4 Palembang applies authoritarian parenting as much as 21 (52.5\%) so that the interpersonal intelligence of children in RA Perwanida 4 is still many that have not developed as many as 17 (42.5\%). Then the correlation results are obtained $r_{x y}=-0,380$ at a significance level of 0.05 with $r_{\text {tabel }}=0,320$. From these calculations show $r_{\text {hit }}>r_{\text {tabel }}$ then $H_{o}$ rejected so hypothesis that shows the relationship between parenting parents with children's interpersonal intelligence is accepted.
\end{abstract}

Keywords: Parenting, Parents, Interpersonal Intelligence

\section{A. Pendahuluan}

Pendidikan bagi seorang anak merupakan salah satu kebutuhannya untuk masa depan. Pendidikan pertama yang diperoleh anak di awal kehidupanya berasal dari keluarga khususnya orang tua, dimana pendidikan yang diberikan itu bisa dalam bentuk pola asuh, sikap atau tingkah laku yang ditampilkan oleh orang tua kepada anak dalam kehidupan sehari-hari (Jannah, 2016). Orang tua harus mampu menerapkan pola asuh yang bisa mengembangkan segala aspek perkembangan anak dan potensi lainnya sedini mungkin. Karena pada hakikatnya orang tua merupakan wadah pertama dalam membentuk sifat masing-masing anak, dimana anak usia dini masih membutuhkan bimbingan orang tuanya. Pola asuh orang tua menjadi faktor penentu bagi anak, apakah anak dapat tumbuh dan berkembang dengan baik atau tidak. Orang tua dituntut harus dapat memahami

This work is licensed under Creative Commons Attribution Non Commercial 4.0 International License Available online on: http://riset.unisma.ac.id/index.php/fai/index 
bagaimana pola pengasuhan yang baik dan benar, agar dapat menghasilkan anak yang berkualitas di masa depan.

Pola asuh orang tua merupakan pola interaksi antara anak dan orang tua selama anak dalam pengasuhan(Fukkink et al., 2019). Di dalam kegiatan pengasuhan, tidak hanya berarti bagaimana orang tua memperlakukan anak, tetapi juga cara orang tua mendidik, membimbing, mendisiplinkan serta melindungi anak untuk mencapai kedewasaan sesuai dengan norma yang berlaku di masyarakat pada umumnya(Susanto, 2015: 26). Pentingnya pola asuh orang tua terhadap anak mengandung arti bahwa pendidikan dalam keluarga merupakan pondasi penting bagi perkembangan pribadi anak. Orang tua yang mampu menyadari akan tanggung jawab dan fungsinya akan mampu menempatkan diri secara lebih baik dan menerapkan pola pendidikan secara lebih tepat sesuai kebutuhan anak. Firman Allah dalam Alquran surat $A n-N a h l$ ayat 93 yang berbunyi:

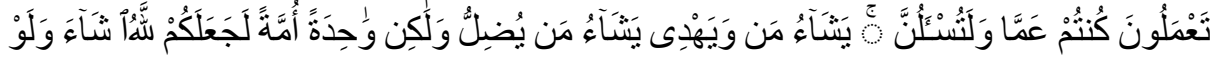

Artinya: Dan kalau Allah menghendaki, niscaya Dia menjadikan kamu satu umat (saja), Tetapi Allah menyesatkan siapa yang dikehendaki-Nya dan memberi petunjuk kepada siapa yang dikehendaki-Nya. Dan sesungguhnya kamu akan ditanya tentang apa yang telah kamu kerjakan (Djamarah, 2014: 47).

Dari uraian ayat di atas menjelaskan tentang pendidikan dan tanggung jawab. Dimana orang tua bertanggung jawab terhadap pendidikan anak dalam keluarga. Segala sesuatu sekecil apapun yang telah dikerjakan dan diperbuat oleh siapa pun, termasuk orang tua akan dipertanyakan dan dipertanggung jawabkan di hadapan Allah SWT. Bagi anak, orang tua adalah model yang harus ditiru dan diteladani. Sebagai model, orang tua seharusnya memberikan contoh yang terbaik dan mencerminkan sikap dan perilaku yang mulia.

Pendidikan anak usia dini adalah suatu upaya pembinaan yang ditujukan kepada anak sejak lahir sampai dengan usia enam tahun yang dilakukan melalui pemberian rangsangan pendidikan untuk membantu pertumbuhan dan perkembangan jasmani dan rohani agar anak memiliki kesiapan dalam memasuki pendidikan lebih lanjut, yang diselenggarakan pada jalur formal, nonformal dan informal (UU Nomor 20 Tahun 2003 Bab I Pasal 1 Ayat 14). Pada masa inilah merupakan masa yang sangat produktif untuk menstimulus segala perkembangan anak. Raudhatul Athfal (RA) merupakan salah satu jenjang pendidikan anak usia dini dalam bentuk pendidikan formal, di bawah Kementrian Agama yang menyelenggarakan program pendidikan dengan kekhasan agama Islam.

Anak usia dini merupakan individu yang berbeda, unik, dan memiliki karakteristik tersendiri sesuai dengan tahapan usianya (Vlasov \& Hujala, 2017). Masa usia dini merupakan masa keemasan (golden age) dimana stimulasi seluruh 
aspek perkembangan berperan penting untuk tugas perkembangan selanjutnya Meity (2015: 49) mengatakan bahwa Golden age merupakan waktu yang paling tepat untuk memberikan bekal yang kuat kepada anak, karena pada masa ini pertumbuhan otak anak sedang mengalami perkembangan yang sangat pesat. Pada masa ini jugalah sangat tepat untuk menggali segala potensi kecerdasan anak sebanyak-banyaknya (Sak, 2015). Masa awal kehidupan anak merupakan masa terpenting dalam rentang kehidupan seorang anak selanjutnya (Piaget, 1977). Sehingga pada masa ini pendidikan berperan penting dalam membantu pertumbuhan dan perkembang anak usia dini.

Anak usia dini dalam kehidupannya tidak hanya sebagai seorang individu tetapi juga sebagai makhluk social (Eurydice, 2009). Sebagai makhluk sosial seorang anak tidak dapat bertahan hidup sendiri tanpa bantuan dari orang-orang di sekitarnya. Dalam memenuhi kebutuhan dirinya anak selalu melibatkan orang lain. Anak harus punya bekal dan kemampuan dalam mengurus diri sendiri serta kemampuan untuk menempatkan dirinya sebagai bagian dari masyarakat

Dalam melaksanakan perannya sebagai makhluk sosial diperlukan kemampuan bekerja sama dengan orang lain, kemampuan ini biasa disebut dengan kecerdasan interpersonal. Kecerdasan ini merupakan keterampilan seseorang memahami dan memperkirakan perasaan, temperamen, suasana hati, maksud dan keinginan orang lain dan menanggapinya secara layak. Sehingga memungkinkan seseorang dapat membangun kedekatan, pengaruh, memimpin, dan berbaur dengan masyarakat (Susanto, 2015: 236). Anak yang memiliki kecerdasan interpersonal biasanya mempunyai banyak teman, pandai bersosialisasi di manapun ia berada dan mampu menjaga hubungan sosial. Kecerdasan interpersonal anak yang satu dengan yang lain tidaklah sama, masing-masing memiliki karakteristik yang berbeda-beda.

Anak yang cerdas interpersonal kemungkinan berasal dari keluarga dengan pola asuh yang demokratis karena anak diberikan kesempatan untuk bertukar pendapat. Anak yang cerdas interpersonal kemungkinan pula berasal dari keluarga dengan pola asuh otoriter karena keluarga tidak berinteraksi baik dengan orangorang di sekitarnya. Lingkungan keluargalah yang memberikan peran dalam pemberian pendidikan dalam perkembangan kecerdasan anak, termasuk kebiasaan orang tua yang ditunjukkan kepada anak (Klein \& Miller, 2018).

Setiap orang tua pasti menginginkan anaknya lebih sukses dari apa yang telah diraih orang tuanya. Sehingga tidak sedikit ditemui orang tua yang masih memaksakan kehendaknya tanpa memperhatikan kebutuhan anak. Orang tua hanya fokus menuntut anak untuk cerdas dan pintar dalam bidang akademik. Ketika bersekolah mereka dihadapkan agar dapat berhitung, membaca dan 
menulis dan mengesampingkan potensi lainnya. Padahal seperti yang kita ketahui bahwa setiap anak yang lahir di dunia ini telah membawa berbagai potensi-potensi lainnya yang dapat dikembangkan.

Setiap anak memiliki jenis kecerdasan yang berbeda-beda(Katz \& Chard, 2000). Orang tua tidak dapat memaksakan anak untuk cerdas disatu bidang tertentu, sementara anak memiliki potensi yang lebih besar pada bidang lain. Dalam teori kecerdasaan majemuk seseorang memungkinkan memiliki banyak kecerdasan dan hanya beberapa saja kecerdasan yang paling menonjol (Morrison, 2007). Oleh karena itu orang tua harus memahami dan mendeteksi sejak dini kecerdasan apa yang paling menonjol pada diri anaknya sehingga dapat dikembangkan secara optimal.

Orang tua memengang peranan penting dalam menumbuh dan mengembangkan potensi kecerdasaan yang dimiliki anak (Vlasov \& Hujala, 2017). Sungguh sangat disayangkan apabila potensi-potensi tersebut tidak dikembangkan secara optimal. Dengan pola asuh yang tepat dapat membantu menggali potensipotensi kecerdasan anak. Pola asuh orang tua yang otoriter yang lebih mengutamakan kedisiplinan yang tidak dibarengi dengan toleransi, wajib menaati peraturan, memaksakan kehendak, yang tidak memberikan peluang bagi anak untuk berinisiatif, maka yang muncul adalah generasi yang tidak memiliki keinginan untuk maju dan berkembang, terbiasa berpikir satu arah dan lain sebagainya. Namun lain halnya bila anak dibiasakan dengan suasana keluarga yang terbuka, saling menghargai, saling menerima dan mendengarkan pendapat anggota keluarganya, maka ia akan tumbuh menjadi generasi yang tebuka, fleksibel, penuh inisiatif, dan produktif, suka akan tantangan dan percaya diri. Kehidupan keluarga merupakan lingkungan pertama dan utama bagi anak. Oleh karena itu, pola pengasuhan orang tua menjadi sangat penting bagi anak dan akan mempengaruhi kehidupan anak hingga dewasa.

Berdasarkan observasi awal yang dilakukan oleh penulis di RA Perwanida 4 Jakabaring Palembang khusunya kelompok B, terdapat tiga tipe pola asuh yakni pola asuh otoriter, pola asuh demokratis dan pola asuh permisif. Dimana dari berbagai tipe pola asuh ini menampilkan berbagai macam karakter anak pada lingkungan sekolah. Ada anak yang mampu menjadi pemimpin, penengah dan pemberi solusi bagi temannya yang lain, ada pula anak yang memiliki empati dan kepedulian terhadap orang lain. Namun selain itu tidak sedikit ditemukan juga anak-anak yang masih suka pilih-pilih teman, tidak pandai bersosialisai dengan lingkungan sekitar, penakut, tidak percaya diri, cengeng dan juga tidak mandiri. Apabila dihadapkan pada kegiatan berkelompok masih ada anak-anak yang tidak 
mau berbagai tugas dan sibuk menampilkan diri sendiri sehingga tidak mampu untuk bekerja secara kelompok.

\section{B. Metode}

Jenis penelitian yang digunakan dalam penelitian ini adalah penelitian kuantitatif yaitu penelitian yang disajikan dalam bentuk angka-angka (Creswell W. John, 2011). Pada penelitian ini peneliti menggunakan metode korelasi yaitu penelitian yang bertujuan untuk mengetahui ada tidaknya hubungan yang positif dan signifikan antara pola asuh orang tua dengan kecerdasaan interpersonal anak di RA Perwanida 4 Palembang. Penelitian ini berlangsung di RA Perwanida 04 Palembang yang terletak di perumahan GGS Komplek MAN 1/ MTS N 1 Jakabaring Palembang. Waktu yang digunakan dalam penelitian ini membutuhkan waktu kurang lebih satu bulan. Satu minggu pertama melakukan penyebaran angket pada orang tua. Satu minggu melakukan observasi mengenai kecerdasaan interpersonal anak. Dan selanjutnya mengumpulkan data pendukung lainnya yang bisa digunakan dalam penelitian. Pada saat melakukan observasi peneliti membutuhkan observer lain untuk dokumentasi.

Adapun target/ sasaran dari penelitian ini yakni anak-anak kelompok B dengan rentang usia 5-6 tahun. Serta yang menjadi subjek penelitian yakni pola asuh orangtua dengan kecerdasan interpersonal anak. Prosedur penelitian ini tentunya peneliti sudah menyiapkan lembar angket dan lembar observasi setelah itu meminta izin pada pihak lembaga, setelah dapat izin barulah peneliti menjelaskan kepada responden cara pengisisan angket, angket disebarkan lalu dikumpulkan kembali, untuk pengisian lembar observasinya dilakukan oleh peniliti kurang lebih 4 hari. Instrument yang digunakan berupa angket /kuesioner untuk pola asuh orang tua dan lembar observasi untuk kecerdasan interpersonal. Kuesioner berupa check list, dengan 24 item pernyataan pola asuh orang tua dengan skala Likert, dan 28 item pernyataan kecerdasaan interpersonal dengan rating scale. Teknik analisis data merupakan kegiatan setelah data dari seluruh responden atau sumber data lain terkumpul. Setelah data terkumpul, maka tahapan selanjutnya adalah melakukan analisis data. Untuk menganalisis data awal dalam penelitian ini, digunakan teknik analisis statistik yang menghitung nilai dan kuantitas dengan cara memberikan penilaian atas jawaban angket yang telah disebarkan kepada responden, di mana masing-masing item diberi alternatif jawaban dengan skor yang tidak sama. 


\section{Hasil dan Pembahasan}

\section{Hasil Penelitian}

Setelah dilakukan pengumpulan data dan tabulasi data, maka didapatkan data sebagai berikut :

Tabel 1 Distribusi Frekuensi Pola Asuh Orangtua

\begin{tabular}{|c|c|c|}
\hline Interval & F & $\begin{array}{c}\text { Persentasi } \\
\mathbf{\%}\end{array}$ \\
\hline $79-81$ & 5 & $12.5 \%$ \\
$82-84$ & 5 & $12.5 \%$ \\
$85-87$ & 14 & $35 \%$ \\
$88-90$ & 7 & $17,5 \%$ \\
$91-93$ & 4 & $10 \%$ \\
$94-96$ & 5 & $12.5 \%$ \\
\hline Jumlah & 40 & $100 \%$ \\
\hline
\end{tabular}

Setelah diperoleh distribusi frekuensi seperti pada tabel di atas, lalu disesuaikan dengan kategori pola asuh yang terbagi kedalam 3 kategori sehingga diperoleh hasil sebagai berikut:

Tabel 2 Pola Asuh Yang Diterapkan Oleh Orangtua

\begin{tabular}{|c|c|c|c|}
\hline No & $\begin{array}{c}\text { Pola Asuh } \\
\text { Orangtua }\end{array}$ & $\begin{array}{c}\text { Jumlah } \\
\text { Responden }\end{array}$ & $\begin{array}{c}\text { Persentase } \\
(\%)\end{array}$ \\
\hline 1. & Demokratis & 9 & 22,5 \\
2. & Otoriter & 21 & 52,5 \\
3. & Permisif & 10 & 25 \\
\hline
\end{tabular}

Pola asuh yang diperoleh dalam penelitian ini melalui penyebaran angket dari 40 responden. Dari hasil kuesioner yang telah didapat dari responden ditemukan mayoritas orangtua anak di RA Perwanida 4 Palembang menerapkan pola asuh otoriter. Hal ini dibuktikan dari hasil kuesioner yang telah didapat dari 40 orang responden, yakni 9 (22.5\%) responden dengan jumlah skor pola asuh nya berkisar 91-96 sudah menerapkan pola asuh yang demokratis. Sedangkan 21 (52.5\%) responden yang jumlah skor pola asuhnya berkisar 85-90 menerapkan pola asuh otoriter. Dan 10 (25\%) menerapkan pola asuh permisif. Jadi dapat dilihat 
bahwa orangtua/wali murid di RA Perwanida 4 Palembang cenderung menerapkan pola asuh otoriter.

Berikut ini terdapat pula data mengenai subject/responden berdasarkan usia, tingkat pendidikan responden dan pekerjaan responden yang dapat mempengaruhi pola asuh orangtua. Karena mayoritas responden untuk pola asuh ini kebanyakan adalah wanita maka data usia, pendidikan dan pekerjaan peneliti hanya mengambil data mengenai usia, pendidikan terakhir ibu dan pekerjaan ibu. Berikut ini tabel distribusi frekuensi responden berdasarkan tingkat pendidikan dan pekerjaan.

Tabel 3 Distribusi Frekuensi Responden Berdasarkan Usia Orangtua

\begin{tabular}{|c|c|c|}
\hline Usia Orangtua & Frekuensi & Persntasi \\
\hline $23-26$ & 1 & $2,5 \%$ \\
\hline $27-30$ & 6 & $15 \%$ \\
\hline $31-34$ & 11 & $27,5 \%$ \\
\hline $35-38$ & 15 & $37,5 \%$ \\
\hline $39-42$ & 3 & $7,5 \%$ \\
\hline $43-46$ & 2 & $5 \%$ \\
\hline $47-50$ & 2 & $5 \%$ \\
\hline Jumlah & $\mathbf{4 0}$ & $\mathbf{1 0 0} \%$ \\
\hline
\end{tabular}

Berdasarkan data di atas dapat dilihat distribusi responden berdasarkan usia orangtua, diperoleh hasil bahwa sebagian besar usia responden berusia 35-38 tahun dengan jumlah 15 orang $(37,5 \%)$.

Tabel 4 Distribusi Frekuensi Responden Berdasarkan Tingkat Pendidikan

\begin{tabular}{|l|c|c|}
\hline $\begin{array}{c}\text { Pendidikan } \\
\text { Responden }\end{array}$ & Frekuensi & Persentase \\
\hline SD & 4 & $10 \%$ \\
\hline SMP & 1 & $2,5 \%$ \\
\hline SMA/SMK & 15 & $37,5 \%$ \\
\hline Perguruan Tinggi & 20 & $50 \%$ \\
\hline Jumlah & $\mathbf{4 0}$ & $\mathbf{1 0 0} \%$ \\
\hline
\end{tabular}


Berdasarkan data di atas dapat dilihat distribusi responden berdasarkan pendidikan, diperoleh hasil bahwa sebagian besar pendidikan responden perguruan tinggi sebanyak 20 orang (50\%).

Tabel 5 Distribusi Frekuensi Responden Berdasarkan Pekerjaan

\begin{tabular}{|l|c|c|}
\hline $\begin{array}{c}\text { Pekerjaan } \\
\text { Responden }\end{array}$ & Frekuensi & Persentase \\
\hline Ibu Rumah tangga & 25 & $62.5 \%$ \\
\hline Wirausaha & 6 & $15 \%$ \\
\hline Pegawai Swasta & 4 & $10 \%$ \\
\hline Guru/PNS & 5 & $12.5 \%$ \\
\hline Jumlah & $\mathbf{4 0}$ & $\mathbf{1 0 0} \%$ \\
\hline
\end{tabular}

Berdasarkan data di atas dapat dilihat distribusi responden berdasarkan pekerjaan, diperoleh hasil bahwa sebagian besar responden tidak bekerja atau menjadi ibu rumah tangga sebanyak 25 orang $(62,5 \%)$.

Tabel 6 Distribusi Frekuensi Kecerdasan Interpersonal

\begin{tabular}{|c|c|c|}
\hline Interval & F & $\begin{array}{c}\text { Persentasi } \\
\text { \% }\end{array}$ \\
\hline $47-54$ & 2 & $5 \%$ \\
$55-62$ & 3 & $7.5 \%$ \\
$63-70$ & 4 & $10 \%$ \\
$71-78$ & 11 & $27.5 \%$ \\
$79-86$ & 14 & $35 \%$ \\
$87-94$ & 6 & $15 \%$ \\
\hline Jumlah & 40 & $100 \%$ \\
\hline
\end{tabular}

Berdasarkan hasil distribusi frekuensi pada tabel di atas, lalu disesuaikan dengan kecerdasan interpersonal yang terbagi kedalam 3 kategori sehingga didapat hasil sebagai berikut: 
Tabel 7 Kriteria Kecerdasan Interpersonal Anak

\begin{tabular}{|c|c|c|c|}
\hline No & Kreteria & $\begin{array}{c}\text { Jumlah } \\
\text { responden }\end{array}$ & $\begin{array}{c}\text { Persentase } \\
\text { (\%) }\end{array}$ \\
\hline 1. & $\begin{array}{c}\text { Berkembang Sangat } \\
\text { Baik }\end{array}$ & 8 & 20 \\
2. & $\begin{array}{c}\text { Berkembang Sesuai } \\
\text { Harapan }\end{array}$ & 15 & 37,5 \\
3. & Belum Berkembang & 17 & 42,5 \\
\hline
\end{tabular}

Berdasarkan hasil analisis di atas dapat dilihat bahwa kecerdasan interpersonal anak di RA Perwanida 4 Palembang masih banyak belum berkembang. Hal ini dapat dilihat pada tabel dimana 17 (42.5\%) anak kecerdasan interpersonalnya belum berkembang dengan jumlah skor berkisar 47-75. Pada kategori berkembang sesuai harapan terdapat 15 $(37,5 \%)$ anak dengan jumlah skor berkisar 76-85. Sedangkan pada katagori berkembang sangat baik terdapat 8 (20\%) anak dengan jumlah skor 86-95. Jadi dapat dilihat bahwa kecerdasan interpersonal anak di RA Perwanida 4 Palembang masih belum berkembang. Adapun hasil dari perhitungan pada tabel koefisien korelasi antara variabel X dan Variabel Y maka dapat diketahui bahwa:

$\begin{array}{ll}\mathrm{N} & \quad=40 \\ \sum \mathrm{X} & =3490 \\ \sum \mathrm{Y} & =3053 \\ \sum \mathrm{XY} & =267095 \\ \sum \mathrm{X}^{2} & =305274 \\ \sum \mathrm{Y}^{2} & =237667\end{array}$

Dari data di atas, masing-masing nilai yang dibutuhkan telah diketahui, maka langkah selanjutnya data di atas dimasukkan ke dalam rumus korelasi Product Moment, sebagai berikut:

\begin{tabular}{|c|c|c|}
\hline \multirow{2}{*}{\multicolumn{2}{|c|}{ rxy }} & $\mathrm{N} . \Sigma \mathrm{XY}-(\Sigma \mathrm{X})(\Sigma \mathrm{Y})$ \\
\hline & & $\sqrt{\left[\overline{\mathrm{N}} \cdot \Sigma \mathrm{X}^{2}-(\Sigma \mathrm{X})^{2}\right]\left[\mathrm{N} \cdot \Sigma \mathrm{Y}^{2}-(\Sigma \mathrm{Y})^{2}\right.}$ \\
\hline & \multirow[t]{2}{*}{$=$} & $40.267095-(3490)(3053)$ \\
\hline & & $\sqrt{\left[40.305274-(3490)^{2}\right]\left[40.237667 .-(3053)^{2}\right.}$ \\
\hline & \multirow[t]{2}{*}{$=$} & $10683800-10654970$ \\
\hline & & $\sqrt{[\overline{12210960-12180100][9506680}}$ \\
\hline & $=$ & 28830 \\
\hline
\end{tabular}




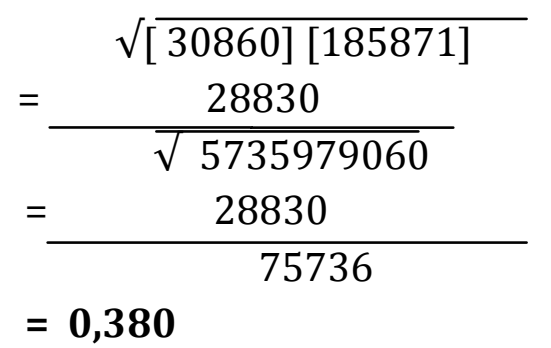

Dari hasil perhitungan tersebut dapat diketahui nilai koefisien korelasi antara pola asuh orangtua dengan kecerdasan interpersonal anak sebesar $-0,380$. Kemudian dibandingakan dengan harga kritik $r$ atau $r_{\text {tabel }}$ dengan taraf signifikan $5 \%$ dan dk $=40-2=38$, maka diperoleh $\mathrm{r}_{\text {tabel }}=0.320$. Karena $r_{\text {hit }}>r_{\text {tabel }}$ yakni $-0.380>0,320$ maka $\mathrm{H}_{0}$ ditolak ini berarti bahwa hipotesis alternative $\mathrm{H}_{a}$ diterima. Sehingga dapat disimpulkan bahwa terdapat hubungan yang signifikan antara pola asuh orang tua dengan kecerdasan anak. Jika nilai $\mathrm{r}_{\mathrm{xy}}=-0,380$ dikonsultasikan pula dengan kriteria korelasi, maka dapat disimpulkan pula bahwa hubungan antara pola asuh orang tua dengan kecerdasan interpersonal anak memiliki hubungan yang rendah. Tanda negative pada nilai " $r$ " menunjukkan bahwa korelasi sejajar berlawanan arah yakni makin tinggi nilai X maka makin rendah nilai Y.

\section{Pembahasan}

\section{a. Pola Asuh Orangtua di RA Perwanida 4 Palembang}

Berdasarkan hasil angket mengenai pola asuh orang tua dari 40 responden yang dilakukan di RA Perwanida 4 Palembang diperoleh data sebanyak $21(52,5 \%)$ orang tua menerapkan tipe pola asuh otoriter. 9 $(22,5 \%)$ orang tua menerapkan tipe pola asuh demokratis. Dan $10(25 \%)$ menerapkan tipe pola asuh permisif. Dari hasil data tersebut dapat diketahui bahwa mayoritas pola asuh orang tua di RA Perwanida 4 Palembang menerapkan pola asuh otoriter. Pola asuh otoriter ini merupakan pola asuh yang kaku suka menghukum, tidak menunjukkan kasih sayang dan tidak simpatik. Orang tua yang otoriter cenderung suka memaksakan kehendaknya sehingga tidak memberikan kesempatan bagi anak untuk mengemukakan pendapatnya, anak tidak dlatih untuk bertanggung jawab dan mengembangkan inisiatifnya sehingga mereka harus mematuhi segala peraturan yang dibuat oleh orangtua.

Kecenderungan orangtua yang menerapkan pola asuh otoriter ini terlihat dari hasil analisis data berdasarkan usia orang tua, tingkat pendidikan terakhir orangtua dan pekerjaan orangtua. Hasil dari analisis data berdasarkan usia orang tua berusia 35-38 tahun sebanyak 15 orang 
$(37,5 \%)$. Hasil analisis data berdasarkan pendidikan terakhir orangtua mayoritas di perguruan tinggi yakni sebanyak 20 orang (50 \%). Sedangkan hasil dari analisis data berdasarkan pekerjaan orang tua diperoleh sebanyak 25 orang $(62,5 \%)$ orangtua tidak bekerja atau sebagai ibu rumah tangga. Hal ini tentunya menjadi suatu kondisi yang dapat mempengaruhi pola asuh yang mereka terapkan. Dengan tingginya pendidikan yang mereka tempuh maka banyak juga informasi yang mereka peroleh sehingga mereka yang tidak bekerja dan hanya fokus pada mengurus anak akan mengontrol secara penuh aktivitas-aktivitas anak. Mereka lebih dominan ingin menampilkan anak yang sesuai dengan keinginan mereka.

\section{b. Kecerdasan Interpersonal Anak di RA Perwanida 4 Palembang}

Selanjutnya berdasarkan hasil observasi tentang kecerdasan interpersonal anak di RA Perwanida 4 Palembang diperoleh data sebanyak 17 (42,5\%) anak pada kategori belum berkembang (BB), 15 (37,5\%) anak pada katagori berkembang sesuai harapan (BSH) dan 8 (20\%) anak pada katagori berkembang sangat baik (BSB). Dari hasil data tersebut dapat diketahui bahwa untuk kecerdasan interpersonal anak di RA Perwanida 4 Palembang ini masih banyak pada kategori belum berkembang yakni sebanyak 17 (42,5\%) anak dan hanya beberapa anak yang sudah dapat berkembang dengan baik. Kecerdasan interpersonal ini merupakan keterampilan seseorang memahami dan memperkirakan perasaan, temperamen, suasana hati, maksud dan keinginan orang lain sehingga memungkinkan seseorang dapat membangun kedekatan, pengaruh, memimpin dan berbaur dengan masyarakat. Artinya dengan berkembangnya kecerdasan interpersonal ini dapat dijadikan sebagai bekal dan kemampuan anak dalam mengurus diri sendiri serta dapat menempatkan dirinya sebagai bagian dari masyarakat. Sehingga sangat disayangkan apabila kecerdasan interpersonal ini tidak dikembangkan sedini mungkin pada anak usia dini.

\section{c. Hubungan Pola Asuh Orangtua dengan Kecerdasan Interpersonal Anak di RA Perwanida 4 Palembang}

Berdasarkan hasil analisis data diatas maka diperoleh koefisien korelasi antara variabel X dan variabel Y yakni antara pola asuh orangtua dengan kecerdasan interpersonal anak sebesar -0,380. Kemudian dikonfirmasikan dengan harga kritik $r$ atau $r_{\text {tabel }}$ dengan taraf signifikan $5 \%$ dan $\mathrm{dk}=40-2=38$, maka diperoleh $r_{\text {tabel }}=0.320$. Karena $r_{\text {hit }}>r_{\text {tabel }}$ yakni - 
$0.380>0,320$ maka $H_{o}$ ditolak ini berarti bahwa hipotesis alternative $\mathrm{H}_{\mathrm{a}}$ diterima. Sehingga dapat disimpulkan bahwa terdapat hubungan yang signifikan antara pola asuh orang tua dengan kecerdasan anak. Jika nilai $r_{x y}$ $=-0,380$ dikonsultasikan pula dengan kriteria korelasi, maka dapat disimpulkan pula bahwa hubungan antara pola asuh orang tua dengan kecerdasan interpersonal anak memiliki hubungan yang rendah.

Tanda negative pada nilai " $r$ " menunjukkan bahwa korelasi sejajar berlawanan arah yakni makin tinggi nilai X (pola asuh orang tua) maka makin rendah nilai Y (kecerdasan interpersonal). Artinya semakin otoriter pola asuh orang tua (tinggi) maka kecerdasan interpersonal anak menjadi rendah sehingga tidak dapat berkembang dengan baik. Sebaliknya jika pola asuh orang tua kurang otoriter maka kecerdasan interpersonal anak akan berkembang dengan baik. Ini berarti pola asuh otoriter terbukti memiliki pengaruh terhadap kecerdasan anak tetapi hubungannya berlawanan terhadap kecerdasan interpersonal anak. Untuk itu agar dapat mengembangkan semua potensi maupun kecerdasan dalam diri anak sebaiknya tidak menerapkan pola asuh otoriter namun sebaiknya menerapkan pola asuh yang demokratis, di mana anak dapat dengan percaya diri untuk mengemukakan segala pendapatnya dan menerima apa yang mereka butuhkan.

Pola asuh orang tua yang otoriter yang lebih mengutamakan kedisiplinan yang tidak dibarengi dengan toleransi, wajib menaati peraturan, memaksakan kehendak, yang tidak memberikan peluang bagi anak untuk berinisiatif, maka yang muncul adalah generasi yang tidak memiliki keinginan untuk maju dan berkembang, terbiasa berpikir satu arah dan lain sebagainya. Namun lain halnya bila anak dibiasakan dengan suasana keluarga yang terbuka, saling menghargai, saling menerima dan mendengarkan pendapat anggota keluarganya, maka ia akan tumbuh menjadi generasi yang tebuka, fleksibel, penuh inisiatif, dan produktif, suka akan tantangan dan percaya diri. Kehidupan keluarga merupakan lingkungan pertama dan utama bagi anak. Oleh karena itu, pola pengasuhan orang tua menjadi sangat penting bagi anak dan akan mempengaruhi kehidupan anak hingga dewasa.

Hasil penelitian ini sejalan dengan penelitian Siti Widhi Astuti (2013) yang menunjukkan hasil bahwa dari 62 responden terdapat 38 $(61,29 \%)$ orang tua menerapkan pola asuh cukup otoriter. Pola asuh otoriter ini dapat menjadikan anak tidak kompeten secara sosial, anak tidak bahagia, ketakutan, minder ketika bersama dengan orang lain, dan memiliki 
komunikasi yang lemah. Anak yang tumbuh dengan kondisi seperti tersebut sangat tidak baik bagi persiapan anak memasuki lingkungan baru untuk bersosialisasi dengan orang di sekitarnya. Penelitian ini pun sejalan dengan yang dikemukaka oleh Milati Azka (2018) yang mengatakan bahwa pola asuh demokratis orang tua merupakan variabel yang ikut memengaruhi kecerdasan interpersonal peserta didik, sehingga semakin tinggi pola asuh demokratis orang tua, maka semakin baik pula kecerdasan interpersonal peserta didik. Sebaliknya semakin rendah pola asuh demokratis orang tua, maka semakin rendah juga kecerdasan interpersonal peserta didik.

\section{Simpulan}

Berdasarkan analisis yang dilakukan dapat disimpulkan bahwa terdapat hubungan yang signifikan antara pola asuh orang tua dengan kecerdasan interpersonal anak usia 5-6 tahun di RA Perwanida 4 Palembang dengan nilai korelasi rendah -0,380 lebih besar dari $r_{\text {tabel }}$ yakni 0,320. Mayoritas orang tua yang menerapkan pola asuh otoriter lebih banyak sehingga kecerdasan interpersonal anak masih banyak belum berkembang. Untuk itu diharapkan kepada para orangtua agar lebih pandai dalam menerapkan pola asuh jangan sampai dapat mempengaruhi anak dalam menggali potensi-potensi mereka.

\section{Daftar Rujukan}

Astuti, Siti Widhi. (2013). "Hubungan Pola Asuh Orangtua dengan Kecerdasan Interpersonal Anak Kelompok B di RA Kecamatan Gondangrejo Kabupaten Karanganyar". Skripsi. Surakarta: Universitas Muhammadiyah.

Creswell W. John. (2011). Educational Research: Planning, Conducting, and

Evaluating Quantitative and Qualitative Research.

Djamarah, Bahri Syaiful. (2014). Pola Asuh Orang Tua dan Komunikasi dalam

Keluarga: Upaya Membangun Citra membentuk Pribadi Anak. Jakarta:Rineka Cipta.

Eurydice. (2009). Early Childhood Education and Care in Europe: Tackling Social and Cultural Inequalities (p. 186). European Commission. https://doi.org/10.2797/18055

Fukkink, R., Jilink, L., Op den Kelder, R., Zeijlmans, K., Bollen, I., \& Koopman, L. (2019). The development of interaction skills in preservice teacher education: A mixed-methods study of Dutch pre-service teachers. Early Childhood Education Journal, 47(3), 321-329. https://doi.org/10.1007/s10643-01900927-7 
Katz, L. G., \& Chard, S. C. (2000). Engaging Children's Minds: The Project Approach. 210.

Klein, A. S., \& Miller, M. (2018). In Support of Family Teacher Partnerships. Early Childhood News.

http://www.earlychildhoodnews.com/earlychildhood/article_view.aspx?Arti cleID $=359$

Morrison, G. S. (2007). Early Childhood Education Today. In M. Girgis (Ed.), Educating Zimbabwe for the 21st Century: What Every Educator Should Know (Third). Pearson. https://doi.org/10.7810/9781927131763_5

Piaget, J. (1977). The Essential Piaget (J. J. V. Howard E. Gruber (ed.); 2nd ed.). J. Aronson.

Sak, R. (2015). Early Child Development and Care Comparison of self-efficacy between male and female pre-service early childhood teachers. July. https://doi.org/10.1080/03004430.2015.1014353

Vlasov, J., \& Hujala, E. (2017). Parent-teacher cooperation in early childhood education-directors' views to changes in the USA, Russia, and Finland. European Early Childhood Education Research Journal, 25(5), 732-746. https://doi.org/10.1080/1350293X.2017.1356536 